\title{
23. STRONTIUM ISOTOPIC COMPOSITION OF THE INTERSTITIAL WATERS FROM LEG 125: MARIANA AND BONIN FOREARCS ${ }^{1}$
}

\author{
Janet A. Haggerty ${ }^{2}$ and Sambhudas Chaudhuri ${ }^{3}$
}

\begin{abstract}
The strontium isotopic data presented here are from interstitial waters squeezed from unconsolidated serpentine, an unusual type of substrate that was recovered from Mariana and Bonin forearc seamounts and has not been previously drilled by the Deep Sea Drilling Project or Ocean Drilling Program. The texture and composition of some of these serpentine deposits from Conical Seamount, located on the Mariana forearc, indicate emplacement as low- or high-viscosity, cold gravitational flows, which are therefore neither sediment nor igneous rock.

The strontium isotopic ratios of the interstitial waters from the unconsolidated serpentine range from 0.70912 to 0.70525 and trend toward a relatively less radiogenic composition with increasing sub-bottom depth. These strontium isotopic ratios are derived from at least two strontium sources: seawater and igneous. The strontium isotopic gradients from the interstitial waters from the Leg 125 sites are probably the result of diffusive transport of strontium from an igneous source deep within the lithosphere that may be contaminated with subducted or underplated sediment.
\end{abstract}

\section{INTRODUCTION}

During Leg 125, we drilled in the Mariana and Izu-Bonin forearcs to determine the origin and evolution of the forearcs and the serpentine seamounts located on them. Sites 778,779 , and 780 were drilled into Conical Seamount, an actively venting serpentine seamount in the Mariana forearc. During submersible dives in 1987 (Fryer et al., 1987; Fryer et al., 1990), fluids were observed seeping from the summit of Conical Seamount, forming chimneys of carbonate minerals and a Mg-silicate mineraloid (Haggerty, 1987b, 1990). Sites 783 and 784 , capped by more than $300 \mathrm{~m}$ of sediment, were drilled into the flanks of Torishima Forearc Seamount, a Bonin serpentine seamount (Horine et al., 1990). Site 781 was drilled in a horst (Marlow et al., this volume) adjacent to Conical Seamount.

This chapter reports strontium isotopic ratios of interstitial water samples from Sites 779, 780, 781, and 784 on the Mariana and Bonin forearcs. It also compares these sample data with results of analyses of aragonite crystals from chimney samples from the summit of Conical Seamount on the Mariana forearc (Haggerty and Chaudhuri, 1989). Finally, this chapter presents a model for derivation of the fluids from at least two sources.

\section{Nature of the Samples}

Most of the samples analyzed for this study were squeezed from cores of serpentine recovered by drilling two serpentine seamounts. No strontium isotopic data has been previously published on interstitial waters squeezed from serpentine materials.

The unconsolidated serpentine is a unique type of substrate that has not been drilled previously by the Deep Sea Drilling Project (DSDP) or Ocean Drilling Program (ODP). These serpentine deposits are primarily composed of serpentine minerals having rare interbedded layers (typically 1 to $2 \mathrm{~cm}$ thick) of a carbonate-poor, pelagic sediment. The serpentine deposits are neither clastic sediments nor igneous rocks, even though field geologists have described a similar type of deposit as a "sedimentary serpentinite" (e.g., Cowan and

${ }^{1}$ Fryer, P., Pearce, J. A., Stokking, L. B., et al., 1992. Proc. ODP, Sci. Results, 125: College Station, TX (Ocean Drilling Program).

${ }^{2}$ Department of Geosciences, University of Tulsa, $600 \mathrm{~S}$. College Ave,., Tulsa, OK 74104, U.S.A

${ }^{3}$ Department of Geology, Thompson Hall, Kansas State University, Manhattan, KS 66506, U.S.A.
Mansfield, 1970). The unconsolidated serpentine is not a true sediment in that the serpentine grains were not deposited particle by particle through the water column. The texture and composition of some of the serpentine deposits indicate emplacement as low- or high-viscosity, cold gravitational flows (Shipboard Scientific Party, 1990a).

Cold unconsolidated serpentine is being extruded near the summit region of Conical Seamount (Fryer et al., 1990). This seamount may have formed by diapiric emplacement of the serpentine body (Shipboard Scientific Party, 1990b, 1990c; Lagabrielle et al., this volume) with the flows forming after the feature breached the seafloor or by repeated protrusions of unconsolidated serpentine flows in the manner of mud volcanoes (Fryer, this volume). In addition to the rare layers of pelagic sediment interbedded with the unconsolidated serpentine, other sedimentary materials are scattered throughout the cores of unconsolidated serpentine from Conical Seamount (Lagabrielle et al., this volume). This interspersed sedimentary material is finely disseminated sediment, detected only by X-ray diffraction identification of mineral components (Fryer and Mottl, this volume; Lagabrielle, this volume), and "xenoliths" of metasediment cobbles in the body of the seamount (Shipboard Scientific Party, 1990c; Lagabrielle et al., this volume). The interspersed sedimentary material may have been entrained during emplacement of the serpentine.

\section{METHODS}

Interstitial water was obtained on board the ship from sediments and unconsolidated serpentine by squeezing. See the "Explanatory Notes" chapter, Initial Reports volume (Shipboard Scientific Party, 1990a) for a detailed description of the extraction of interstitial waters from the cores.

Most of the samples selected for strontium isotopic analysis were obtained from the forearc seamounts. Two samples from Hole 784A (Cores 125-784A-14R and -32R) in Torishima Forearc Seamount (Bonin forearc) were squeezed from pelagic sediment overlying serpentine materials. Asample squeezed from pelagic sediment was also selected for strontium isotopic analysis from Site 781. This site is located on a horst adjacent to Conical Seamount and did not yield serpentine.

Strontium isotopic ratios of the interstitial water samples were determined in the Strontium Isotope Laboratory at Kansas State University. Strontium was separated by standard ion exchange pro- 
cedures. The ${ }^{87} \mathrm{Sr} /{ }^{\beta 6} \mathrm{Sr}$ ratios were determined from the $\mathrm{Sr}$ concentrates using a VG mass spectrometer in the dynamic multicollector mode. The isotopic ratios were normalized to ${ }^{87} \mathrm{Sr} /{ }^{86} \mathrm{Sr}=$ 0.1194. Measurements of the Sr isotopic ratios of the NBS 987 standard during the analyses of the water samples averaged 0.710245 with two standard deviations of 0.000011 .

\section{RESULTS}

Table 1 lists the strontium isotopic ratios of the interstitial water samples analyzed from Leg 125; these values document at least two sources of strontium. Present-day seawater ${ }^{87} \mathrm{Sr} /{ }^{86} \mathrm{Sr}$ falls in the range from $0.709241 \pm 0.000032$ to $0.709211 \pm 0.000037$ (Elderfield, 1986). All of the ${ }^{87} \mathrm{Sr} /{ }^{86} \mathrm{Sr}$ values are less than those of present-day seawater. The isotopic values range from 0.70912 (near the ${ }^{87} \mathrm{Sr} /{ }^{86} \mathrm{Sr}$ range for seawater) to as low as 0.70525 . These document an additional source of strontium other than present-day seawater.

Figure 1 illustrates the decrease in the ${ }^{87} \mathrm{Sr} /{ }^{86} \mathrm{Sr}$ ratio of the interstitial waters with increasing sub-bottom depth within the serpentine bodies and shows for comparison the sample from 188.7 meters below seafloor (mbsf) from Site 781. This interstitial water sample was squeezed from a vitric clayey silt and vitric silt. The strontium isotopic ratio of this sample is significantly different from modern seawater values, which may be explained by the contribution of strontium from the alteration of igneous components within the sediment or of olivine-plagioclase phyric basalt at 72.6 to $91.8 \mathrm{mbsf}$.

\section{DISCUSSION}

The strontium isotopic ratios of the interstitial waters range from near-seawater values to significantly lower values, suggesting that one strontium source is seawater. This interpretation is consistent with those derived from the oxygen isotopic composition of aragonite crystals and the composition of some fluid inclusions trapped within the aragonite crystals associated with chimneys atop Conical Seamount (Haggerty, 1987b, 1990).

Some of the values presented in Table 1 are significantly lower than any seawater strontium isotopic values and most are significantly lower than 0.708 to 0.709 , the typical range for Neogene seawater (DePaolo, 1986; Hodell et al., 1989). The variation in the strontium isotopic composition of the interstitial waters from these serpentine bodies cannot be totally ascribed to the contribution from a marine strontium source.

The strontium isotopic composition of the interstitial waters cannot be explained as present-day seawater modified by the recrystallization of carbonate sediments near the seafloor. Modification of the strontium isotopic composition of interstitial water by diagenetic changes associated with carbonates typically results in values that approach an equilibrium between interstitial waters and the carbonates (Gieskes et al., 1986).

At these drill sites, an abundant supply of pelagic carbonates capping the seamounts or interlayered in the serpentine is not available. On the basis of a sparse assemblage of nannofossils, the oldest pelagic sediment (possibly reworked) on Conical Seamount was dated as lower Pliocene (?) or upper Miocene (?) (Shipboard Scientific Party, 1990b). Biostratigraphic dating of nannofossils and diatoms in the sediments overlying the serpentine body (associated with Site 784 on Torishima Forearc Seamount in the Bonin region) indicates that deposition took place during the middle Miocene to late Pleistocene (Shipboard Scientific Party, 1990d). Even if carbonate pelagic sediment were abundantly present and contributed strontium during dissolution shortly after deposition, the isotopic composition of the strontium contributed would have been similar to present-day seawater or at least similar to late Neogene seawater. The strontium isotopic ratios of authigenic aragonite from chimneys near the summit of the seamount range from 0.70912 to 0.70879 (Haggerty and Chaudhuri, 1989); most are slightly lower than present-day seawater.

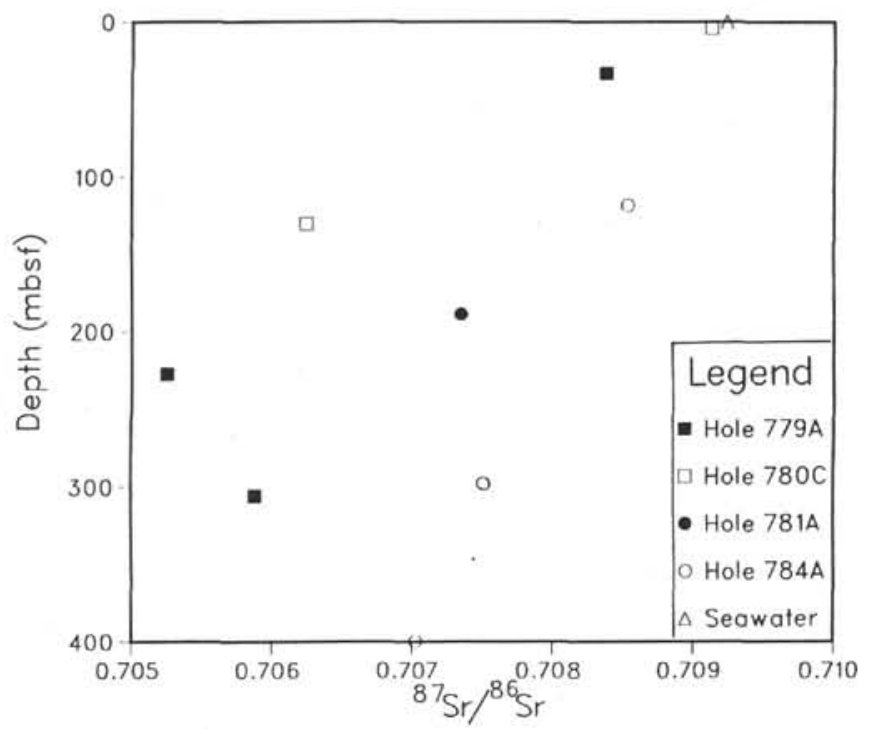

Figure 1. A comparison of the strontium isotopic ratios of the Leg 125 interstitial water samples with modern seawater ${ }^{87} \mathrm{Sr}{ }^{86} \mathrm{Sr}$. See Table 1 for data. Strontium isotopic ratios of interstitial water samples from Hole $779 \mathrm{~A}$ (solid squares), a flank hole; from Hole $780 \mathrm{C}$ (open squares), a summit hole in Conical Seamount; from Hole 781A (solid circle), a hole in the horst adjacent to Conical Seamount; from Hole 784A (open circles), a hole in the flank of Torishima Forearc Seamount; and of modern seawater (open triangle) plotted against depth in meters below seafloor (mbsf).

Thus, contribution of strontium from a local carbonate source would not explain the strontium isotopic ratios of these interstitial waters associated with the serpentine seamounts.

The absence of a large accretionary prism in the Mariana and Bonin forearcs removes the complication of a strontium source associated with fluids generated from dewatering of a sediment prism by compression during convergence. If a strontium source is associated with the dewatering of sediment, it is related to the subducted or possibly underplated sediment (Haggerty, 1987b, 1989, 1990), that is significantly older than Neogene.

At least two strontium sources may be responsible for both (1) the strontium isotopic composition of fluids forming chimneys of carbonate minerals and a Mg-silicate mineraloid on the summit of Conical Seamount (Haggerty, 1987a, 1987b, 1989, 1990; Haggerty and Chaudhuri, 1989) and (2) the composition of the interstitial waters

Table 1. Strontium isotopic values of interstitial waters from Leg 125.

\begin{tabular}{lrc}
\hline $\begin{array}{c}\text { Interstitial water sample } \\
\text { Hole, core, section, interval }(\mathrm{cm})\end{array}$ & $\begin{array}{c}\text { Depth } \\
(\mathrm{mbs})\end{array}$ & $\begin{array}{c}{ }^{87} \mathrm{Sr} /{ }^{86} \mathrm{Sr} \\
( \pm \text { standard deviation) }\end{array}$ \\
\hline $\begin{array}{l}\text { Flank of Conical Seamount } \\
\text { 779A-5R-3, 46-56 }\end{array}$ & 33.1 & $0.70837( \pm 0.000009)$ \\
779A-28R-2, 105-110 & 227.4 & $0.70525( \pm 0.000010)$ \\
779A-36R-2, 135-150 & 305.9 & $0.70588( \pm 0.000009)$ \\
& & \\
Summit of Conical Seamount & 3.9 & $0.70912( \pm 0.000010)$ \\
780C-1R-3, 140-150 & 129.9 & $0.70624( \pm 0.000012)$ \\
780C-15R-1, 38-48 & & \\
& & \\
Off Conical Seamount, & & \\
Mariana forearc site & 188.7 & $0.70735( \pm 0.000010)$ \\
781A-21R-CC, 30-36 & & \\
Torishima Forearc Seamount & 118.1 & $0.70853( \pm 0.000010)$ \\
784A-14R-1, 140-150 & 297.8 & $0.70751( \pm 0.000010)$ \\
784A-32R-5, 140-150 & 399.5 & $0.70703( \pm 0.000010)$ \\
784A-43R-2, 135-150 & &
\end{tabular}


from the serpentine seamounts (Mottl et al., 1989; Shipboard Scientific Party, 1990c; Haggerty, 1990). Trace element compositions, carbon, oxygen, and strontium isotopic compositions, fluid inclusions trapped within the aragonite that formed the chimneys (Haggerty, 1987a, 1989, 1990; Haggerty and Chaudhuri, 1989), and the chemical composition and organic acid assemblage within the interstitial waters (Mottl et al., 1989; Haggerty, 1990; Haggerty and Fisher, this volume) all indicate that one source of strontium is seawater and another is igneous.

If seawater were actively and abundantly circulating through these serpentine seamounts (producing a high seawater/rock ratio), one might expect the strontium isotopic ratio from a possible igneous source to become swamped by that from seawater, even at depth within the serpentine seamount. The strontium isotopic composition of circulating seawater can indeed be lowered by reaction with partially to completely serpentinized harzburgites and dunites. However, if the seawater/rock ratio is high and the rocks have a low strontium concentration, as do the serpentinized rocks from these sites (Shipboard Scientific Party, 1990c), then it is unlikely that low strontium isotopic ratios of interstitial waters will result. The trend in the strontium isotopic compositions of the interstitial waters with increasing sub-bottom depth suggests that the importance of seawater as a strontium source is greatest near the serpentineseawater interface.

The hypothesis that seawater interactions with serpentine are not solely responsible for the shift in strontium isotopic ratio of the interstitial water from present-day seawater ${ }^{87} \mathrm{Sr} /{ }^{86} \mathrm{Sr}$ is also supported by research conducted on aragonite associated with serpentinite on the seafloor at fracture zones. The aragonite associated with fracturezone serpentinite has a strontium isotopic ratio similar to that of present-day seawater (Bonatti et al., 1980). Strontium isotopic ratios of aragonite associated with chimneys on Conical Seamount are different from that of present-day seawater ${ }^{87} \mathrm{Sr} /{ }^{86} \mathrm{Sr}$ and therefore also retain an imprint from an igneous source (Haggerty and Chaudhuri, 1989), even though the aragonite in the chimneys formed on the seafloor.

Separate strontium isotope gradients probably exist for interstitial waters collected from each hole; the isotopic gradient is apparent for the waters from Hole 784A (Fig. 1). Strontium isotopic gradients have been reported previously in several studies of interstitial waters from a number of DSDP sites (Hawkesworth and Elderfield, 1978; Gieskes et al., 1982; Elderfield et al., 1982); these have been interpreted as concentration gradients which are the result of strontium diffusing from a layer of volcaniclastic-carbonate sediment or a basaltic layer below the seafloor to the seawater near the sediment/seawater interface. Diffusive transport of strontium from some igneous source at sub-bottom depths below the deepest collecting horizon is a likely cause for the observed strontium gradients for interstitial waters from the Leg 125 sites for two reasons: (1) the lack of any significant amount of carbonate sediment capping the seamounts or interlayered with the serpentine material, and (2) the waters have strontium isotopic values as low as about 0.705 . Potential variations in the strontium isotopic gradients could be related to variations in the porosity of the rock column between the underlying source with the high strontium concentration and the overlying seawater. Chemical and stable isotopic data need to be integrated with the strontium isotopic data for a definition of the igneous source of the strontium.

A source that might contribute lower strontium isotopic values than those in seawater must be sought from deep within the lithosphere. The strontium isotopic composition of the present-day upper mantle has been suggested as approximately $0.704 \pm 0.002$, whereas seafloor oceanic tholeiites average approximately 0.70280 and island-arc andesites average approximately 0.70437 (Faure, 1977). Considering the complexity of the tectonic setting of the Mariana and Bonin forearcs (Johnson, this volume; Pearce et al., this volume), any one or all of these igneous sources could potentially contribute strontium and therefore be a source of the lower strontium isotopic ratios observed in the interstitial water samples.

From the strontium isotopic data presented here, it is impossible to determine the specific igneous source or sources that may have caused the decrease in the strontium isotopic ratio. Furthermore, it is possible that the strontium isotopic ratio of the interstitial waters reflects fluids not only derived from a deep, igneous source, but also contaminated subsequently by a sediment source. Such contaminating fluids may derive from the downgoing slab or underplated sediment. With sufficient pressure and temperature changes during subduction of an oceanic plate, fluids can be derived from pelagic sediment and hydrated basalt composing the subducted slab or underplated material. These fluids may act as a flux to cause melting of the subducted slab or underplated material and metamorphose the overlying mantle or plate to form serpentine (a lower density medium). If the serpentine seamounts drilled on Leg 125 are sites where serpentine rises to the seafloor, then the seamounts could provide a conduit for transport of fluid from a deep source. Faure (1977) noted that contamination of magma sources with sediment could explain the strontium isotopic ratios of andesites that are higher than mantle values. The ultimate strontium isotopic compositions of magma, expelled fluids, or diapiric material are functions of the composition and degree of melting of the parent material and the interactions of the magma, fluids, or diapiric material with the surrounding country rock during migration upward or to the seafloor. Supporting evidence for contamination of the fluids derived from an igneous source with the fluids derived from pelagic sediments is the existence of finely disseminated sediments and sedimentary pebbles within the unconsolidated serpentine that probably were entrained during the rise of the serpentine.

\section{CONCLUSIONS}

The strontium in the interstitial waters associated with serpentine drilled in the Mariana and Bonin forearcs is derived from more than one source. The strontium isotopic ratios are intermediate between seawater and igneous rocks. One source is seawater. Oxygen and strontium isotopic data, as well as fluid inclusion data from authigenic aragonite that is associated with active seeps near the summit of Conical Seamount (Haggerty, 1987a, 1989, 1990; Haggerty and Chaudhuri, 1989) support this conclusion. The other source is igneous, perhaps from deep within the lithosphere and possibly contaminated with subducted or underplated pelagic sediment. Diffusive transport of strontium from a deep igneous source is a likely cause for the observed strontium gradients of the interstitial waters from the Leg 125 sites.

\section{ACKNOWLEDGMENTS}

We thank the Leg 125 Scientific Party and the shipboard personnel of the JOIDES Resolution for collecting the samples. J. A. Haggerty thanks the JOI-USSAC Committee for support of the post-cruise science and NSF grant no. OCE-8721871 for supporting our strontium isotopic analyses of aragonite materials retrieved by the Alvin from Conical Seamount. We also thank the reviewers for their help with this manuscript.

\section{REFERENCES}

Bonatti, E., Lawrence, J. R., Hamlyn, P. R., and Breger, D., 1980. Aragonite from deep sea ultramafic rocks. Geochim. Cosmochim. Acta, 44:12071214.

Cowan, D. S., and Mansfield, C. F., 1970. Serpentine flows on Joaquin Ridge, southern coast ranges, California, Geol. Soc. Am. Bull., 81:2615-2628.

DePaolo, D. J., 1986. Detailed record of the Neogene Sr isotopic evolution of seawater from DSDP Site 590B. Geology, 14:103-106.

Elderfield, H., 1986. Strontium isotope stratigraphy. Palaeogeogr., Palaeoclimatol., Palaeoecol., 57:71-90. 
Elderfield, H., Gieskes, J. M., Baker, P. A., Oldfield, R. K., Hawkesworth, C. J., and Miller, R., 1982. ${ }^{87} \mathrm{Sr} /{ }^{86} \mathrm{Sr}$ and ${ }^{18} \mathrm{O} /{ }^{16} \mathrm{O}$ ratios, interstitial water chemistry and diagenesis in deep-sea carbonate sediments of the Ontong Java Plateau. Geochim. Cosmochim. Acta, 46:2259-2268.

Faure, G., 1977. Principles of Isotope Geology (2nd ed.): New York (Wiley and Sons).

Fryer, P., Haggerty, J. A., Tilbrook, B., Sedwick, P., Johnson, L. E., Saboda, K. L., Newsom, S. Y., Karig, D. E., Uyeda, S., and Ishii, T., 1987. Results of studies of Mariana forearc serpentine diapirism. Eos, 68:1534

Fryer, P., Saboda, K. L., Johnson, L. E., MacKay, M. E., Moore, G. F., and Stoffers, P., 1990. Conical seamount: SeaMARC II, Alvin submersible, and seismic reflection studies. In Fryer, P., Pearce, J. A., Stokking, L. B., et al., Proc. ODP, Init. Repts., 125: College Station, TX (Ocean Drilling Program), 69-80.

Gieskes, J. M., Elderfield, H., Lawrence, J. R., Johnson, J., Meyers, B., and Campbell, A., 1982. Geochemistry of interstitial waters and sediments, Leg 64, Gulf of California. In Curray, J. R., Moore, D. G., et al., Init. Repts. DSDP, 64 (Pt. 2): Washington (U.S. Govt. Printing Office), 675-694.

Gieskes, J. M., Elderfield, H., and Palmer, M. R., 1986. Strontium and its isotopic composition in interstitial waters of marine carbonate sediments. Earth Planet. Sci. Lett., 77:229-235.

Haggerty, J. A., 1987a. Petrology and geochemistry of Neogene sedimentary rocks from Mariana forearc seamounts: implications for emplacement of the seamounts. In Keating, B., Fryer, P., and Batiza, R. (Eds.), Seamounts, Islands, and Atolls. Am. Geophys. Union., AGU Monogr. Ser., 43:175-185.

, 1987b. Cold-water, deep-sea chimneys from the Mariana forearc serpentinite seamounts. Eos, 68:1534.

, 1989. Fluid inclusion studies of chimneys associated with serpentinite seamounts in the Mariana forearc. PACROFI II, 2:29. (Abstract)

, 1990. Fluid seeps atop serpentinite seamounts in the Mariana Forearc. AAPG 1990 Ann. Conv. (Abstracts), 96-97.

Haggerty, J. A., and Chaudhuri, S., 1989. Strontium isotopic analyses of aragonite from cold-water chimneys atop Mariana forearc seamounts: implications for fluids from the subducting slab. Eos, 70:1380.

Hawkesworth, C. J., and Elderfield, H., 1978. The strontium isotopic composition of interstitial waters from Sites 245 and 336 of the Deep Sea Drilling Project. Earth Planet. Sci. Lett., 40:423-432.

Hodell, D. A., Mueller, P. A., McKenzie, J. A., and Mead, G. A., 1989. Strontium isotope stratigraphy and geochemistry of the late Neogene ocean. Earth Planet. Sci. Lett., 92:165-178.

Horine, R. L., Moore, G. F., and Taylor, B., 1990. Structure of the outer Izu-Bonin forearc from seismic-reflection profiling and gravity modeling. In Fryer, P., Pearce, J. A., Stokking, L. B., et al., Proc. ODP, Init. Repts., 125: College Station, TX (Ocean Drilling Program), 81-94.

Mottl, M. J., Haggerty, J. A., and Scientific Party of Ocean Drilling Program Leg 125, 1989. Upwelling of Cl-poor, S- and C-rich waters through a serpentinite seamount, Mariana Forearc: ODP Leg 125. Eos, 70:1382.

Shipboard Scientific Party, 1990a. Explanatory notes. In Fryer, P., Pearce, J. A., Stokking, L. B., et al., Proc. ODP, Init. Repts., 125: College Station, TX (Ocean Drilling Program), 15-40.

1990b. Site 779. In Fryer, P., Pearce, J. A., Stokking, L. B., et al., Proc. ODP, Init. Repts., 125: College Station, TX (Ocean Drilling Program), 115-145.

1990c. Site 780. In Fryer, P., Pearce, J. A., Stokking, L. B., et al., Proc. ODP, Init. Repts., 125: College Station, TX (Ocean Drilling Program), 147-178.

, 1990d. Site 784. In Fryer, P., Pearce, J. A., Stokking, L. B., et al. Proc. ODP, Init. Repts., 125: College Station, TX (Ocean Drilling Program), 273-305.

Date of initial receipt: 21 November 1990

Date of acceptance: 22 July 1991

Ms 125B-124 